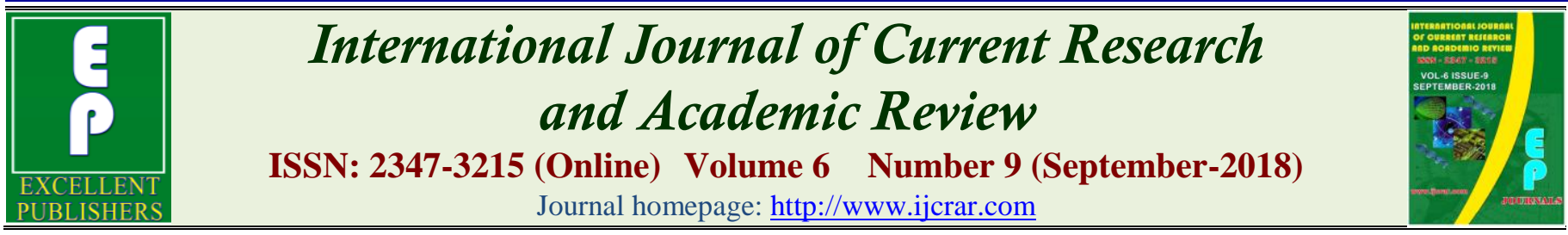

doi: https://doi.org/10.20546/ijcrar.2018.609.005

\title{
Analysis of the Nexus between Gross Domestic Savings and Economic Growth in Ethiopia: Evidence from Toda-Yamamoto Causality Approach
}

\author{
Zelalem Adugnaw Welela* \\ Development Bank of Ethiopia \\ *Corresponding author
}

\section{Abstract}

Aware of the interaction between gross domestic savings and economic growth is critically importance for policy option. However, the wide range of controversies surrounding the direction of causality between savings and economic growth motivated this study. Therefore, the objective of this study is intended to investigate empirically the Nexus between gross domestic savings and economic growth in Ethiopia using annual time series data spanning through a period of 42 years (1976 to 2017) obtained from MoFEC and annual reports of NBE. The study employed recently developed methods of autoregressive distributed lag (ARDL) approach to cointegration test and the augmented Granger causality test approach developed by Toda and Yamamoto (1995) so as to achieve this objective. After performing robustness checks, ARDL bounds to co integration test can be concluded that there is significant evidence that gross domestic savings and economic growth are co-integrated, and therefore hold a long run relationship exists between them. Error correction model also identified the presence of short run relationship. The Toda and Yamamoto version of granger causality test reveals that causality runs from economic growth to gross domestic savings, implying that economic growth precedes and granger causes saving. Thus, the study rejects the Solow's hypothesis that saving precedes economic growth, and accepts the Keynesian theory that economic growth leads to higher saving. As a result, the study recommends that government and policy makers should focus on income policies that would accelerate economic growth so as to increase saving.
\end{abstract}

\section{Article Info}

Accepted: 15 August 2018

Available Online: 20 September 2018

\section{Keywords}

Economic growth, Gross domestic Savings, Co-integration test, Granger causality test, Ethiopia

\section{Background of the Study}

The rate of economic growth in any economy depends on the level of investment made in different sectors of that economy; and there cannot be any meaningful investment without saving. Nevertheless, low saving rates have been identified as one of the major growthinhibiting factors among countries in the world, especially in developing countries (Getenet, 2017). The slow rate of development in third world countries are usually attributed to the low levels of national saving, that constraint their capacity to invest in capital formation. This leads to lower level of economic growth and development than other countries that contribute enough savings (Jagadeesh, 2015). It is observed that economies witnessing rapid economic growth such as China, India, Indonesia, Malaysia, Singapore, South Korea and Thailand, etc. also characterized by high domestic saving rates during their developmental phase. Similarly, many countries in sub-Saharan Africa and Latin America typically save at a low rate and experience slow economic growth (Patra et al., 2017). 
Ethiopia is one of among the low-income sub-Sahara African countries which needs fast and sustainable economic growth. However, low domestic saving rate is consistently cited as one of the most serious constraints to sustainable economic growth. The rate of gross domestic saving was 22.4 percent of GDP in 2015/16; whereas the share of gross domestic investment to GDP was 38.5 percent in 2015/16 and resource gap (trade deficit) was 19.8 at the same time (MoFEC, 2016).

Ethiopia has adopted policy reforms of the five year Growth and Transformation Plan (GTP) for the period between 2015/16 to 2019/20 to sustain rapid and broadbased economic growth and eventually end poverty. It has also set out an objective to achieve an annual average real GDP growth rate of $11 \%$ to $14.9 \%$ over these years with in a stable macro-economic environment. To implement these growth and transformational plan requires huge investment through increasing domestic savings via a host of reform measures so as to provide the required finances to deliver Growth and Transformation Plan. GTP focused on enhancing domestic saving and investment coupled with job creation is indeed a critical element of the strategy to foster economic growth and structural change for the delivery of GTP goals (Yinagre, 2016). Accordingly, a sound understanding of the interaction between savings and economic growth in a country's economy is strategically important for the achievement of macroeconomic policy to sustainable economic growth and hence higher standard of living of citizens. Therefore, the present study attempts to examine the causal relationship between gross domestic savings and economic growth, using augmented Granger causality test. More specifically, the purpose of our paper is to determine whether increases in gross domestic savings Granger-cause economic growth rate or vice versa. This is what this paper intends to achieve.

\section{Problem Statement}

One of the most controversial issues in macroeconomics is the direction of causal relationship between gross domestic savings and economic growth. This is because of divergent opinions in theories and mixed empirical results among various literatures (Bolarinwa \& Obembe, 2017). In the theories, for example, the neoclassical school believes that higher savings lead to higher growth rates. This is plausible because increase in saving can stimulate economic growth through the mechanism of investment (Pickson et al., 2017). Neoclassical works like Harrod (1939), Domar (1946), Lewis (1955), Solow
(1956) and Romer (1986) are based on this theoretical viewpoint. These works are grounded on the conventional viewpoint that higher savings lead to higher investment and consequently imply higher economic growth; thus, these works suggest the formulation of macroeconomic policies that stimulate aggregate saving to achieve economic growth. So, from the neoclassical principle, causality runs from saving to economic growth. On the other hand, the Keynesian schools conflict with the classical opinion and postulate that economic growth leads to savings in the economy. The Keynesian opinion is based on the standpoint that saving is a leakage which depends on income (Keynes, 1936). Therefore, saving is an outcome of income and not its determinant (Tang \& Tan, 2014). On this the Keynesian opinion, several macroeconomic works have been rooted (Modigliani, 1970; Carroll \& Weil, 1994; Agarwal, 2001). So, from Keynesian perspective, it is expected that causality runs from economic growth to saving.

In spite of difference of opinions in theories; empirical researches on the issue of the direction of causality between gross domestic savings and economic growth in Ethiopia are not extensive, and the findings or conclusions of some of them are not consistent with one another. For instance Ibrahim (2014) has reported causality running from economic growth to saving, while Mohanty (2017) found bidirectional relationship. At the same time Getenet, 2017 reported that saving and economic growth are independent of each other. Meanwhile, the existing studies continue to yield conflicts and inconclusiveness depending on measure of variables and techniques adopted. Most of such existing studies used ordinary Granger causality test method developed by Granger (1969). But ordinary Granger causality test has probable shortcomings of specification bias and spurious regression. To mitigate these problems, Toda and Yamamoto (1995) developed a procedure based on augmented VAR modeling, by introducing a modified Wald test statistic (MWALD) since it avoids the potential bias associated with unit roots and cointegration tests as it can be applied regardless of whether a series is non co-integrated or co-integrated of an arbitrary order, thereby yielding consistent and unbiased estimates (Toda and Yamamoto, 1995; and Dolado and Lutkepohl, 1996).

Therefore, this article employs a more robust augmented granger causality test approach developed by Toda and Yamamoto (1995) to examine the causal relationship between gross domestic savings and economic growth within the dynamic VAR framework, thereby filling a 
methodological gap. To the best of the knowledge of the researcher, no study has employed this technique among the studies on Ethiopia on the subject matter. Motivated by this fact, this study contributes towards filling this gap.

\section{Objectives of the Study}

The main objective of this study is to investigate empirically the nexus between gross domestic savings and Economic growth over the period of 1976-2017 in Ethiopia. Specifically, the study tries to address the following specific objectives:

To examine the existences of long run relationship between gross domestic savings and economic growth in Ethiopia based on empirical evidence.

To provide empirical evidence on the causal relationship between gross domestic savings and economic growth and the particular direction of causality between them.

\section{Hypothesis of the Study}

In line with the aforementioned objectives, the study tried to test the following hypotheses in null forms:

There is no long run relationship between gross domestic savings and economic growth in Ethiopia.

There is no any direction of causation between gross domestic savings and economic growth in Ethiopia.

\section{Literature Review}

\section{Theoretical Literature Review}

Theoretical postulations on the relationship between saving and economic growth started during the time of Adam Smith (Tang \& Tan, 2014). Adam Smith says the economy needs industrialization to achieve economic growth. Not recognizing other sources of finance such as foreign direct investment (FDI) during the period, Smith submitted that industrialization can only be achieved through adequate capital accumulation. According to him, capital accumulation is strongly and positively related to the rate of saving. This means society can only accumulate capital through the increased saving. We, therefore, expect higher saving rate that will lead to an increase in capital accumulation and, consequently, higher economic growth following the thought of Adam Smith.
The classical model of Harrod (1939) and Domar (1946) of economic growth is another theory that relates the two variables. The model submitted that in an economy with a particular level of technological advancement, the rate of economic growth is directly related to the rate of capital accumulation. Like Smith's proposition, this capital accumulation is determined by the rate of saving in an economy. As a result, higher saving rate implies higher capital accumulation and, consequently, higher economic growth. Also, from the perspective of neoclassical school, Solow and Swan (1956) expanded the Harrod and Domar model. They clearly state that saving is a determinant of economic growth. Other determinants are population growth rate and technical progress. To them, saving affects investment and investment in an economy is directly proportional to economic growth. So at the equilibrium level, saving is equal to investment. However, unlike the Harrod and Domar model, the influence of saving on economic growth is temporary in the short run due to the law of variable proportions employed in their theory. What actually determines economic growth is technological advancement, which is not determined within the confinement of economic theories. The neoclassical school of thought, therefore, fails to provide an answer to the question of the determinants of economic growth in the long run, and to them what determines economic growth in the short run is technological advancement, which is not explained within the framework of economic theories. This is what gave birth to the endogenous growth theory led by Lucas (1988) and Romer (1986). So, from the classical school of thought, we expect that saving Granger causes economic growth.

From the Keynesian school of thought, saving is seen as a function of income, since income can either be spent on the consumption of goods and services or saved. At the same time, a rational consumer might decide to share his income between the two. The school, therefore, concludes that income determines gross domestic saving in the economy. So, if national income grows, then per capita income will increase, and consequently the share of per capita income on saving and consumption will increase depending on the rate of increase and the magnitude of previous income. For developed countries where the existing level of per capita income is high, it is expected that the higher proportion of increase in income will be channeled to saving and this will increase the level of investment in the economy, thereby leading to economic growth. However, for developing countries, where the existing level of per capita income is low, higher proportion of increase in per capita income is 
expected to be channeled to consumption and, thereby increasing firms' profits. As a result, firms will hire more labor and capital, and the economy will grow. So, from the Keynesian point of view, economic growth is expected to Granger Cause saving in sub-Saharan African economies.

\section{Reviews of Empirical Literature}

The nexus between savings and economic growth has significant policy implications, as previously noted. As a result, several empirical studies have been carried out on the subject. This section presents a succinct summary of studies related to the relationship between savings and economic growth. Jagadeesh (2015) examined the Impact of Savings on Economic Growth in Botswana during 1980 to 2013 using Auto Regressive Distributed Lagged (ARDL) model and DOLS test to check the existence of a long run relationship between GDP and GDS through identified dynamic long run co-integration between GDP and its independent variables. She supported Harrod-Domar growth model that saving rate positively or directly related to GDP.

Odionye and Ugwuegbe (2016) examined the causal relationship between domestic private savings and economic growth in Nigeria for the period of 1980 to 2013. The study employed the augmented Granger causality test approach developed by Toda and Yamamoto (1995).

The result showed a strong unidirectional causality from domestic private savings to economic growth in Nigeria. The result supported the Solow's hypothesis. Also the evidence from Johansen co-integration result indicated that there is a positive long run relationship between domestic savings and economic growth.

Hashmi and Sedai (2016) investigated the relationship between domestic saving and economic growth in India by employed ARDL model and Granger causality test. They confirmed that the existence of bi-directional granger causality between domestic savings rate and GDP growth for India. It is in line with both Keynesian hypothesis and Solow growth theory.

Zinyurugwi and Mapfumo (2016) examined the relationship between domestic savings and economic growth in Zimbabwe using secondary time series data from 1980 to 2015. They employed the Engle-Granger residual based co-integration method. The study found that gross domestic savings movements do not significantly impact on the changes in economic growth in Zimbabwe. According to their research there is no long run relationship between domestic savings and economic growth.

Pickson et al., (2017) studied the relationship between gross domestic savings and economic growth in Ghana over the period of 1972 to 2013 using Johansen cointegration test and VAR technique. They found that there was a unidirectional line of causation running from gross domestic savings to economic growth in the short run.

Patra et al., (2017) examined the association and direction of causality between savings and real economic activity in Indian context for the period 1950-51 to 2011-12 by employed Johansen and Juselius (1990) and Johansen (1991) and vector error correction mechanism (VECM). The study identifies the structural break in the year 1980 by employing Bi-Perron test with unknown time. They revealed that saving and real economic activity have long run relationship in both the pre and post break period and the causality results obtained under the VECM framework reveals that in the long run, saving causes economic growth while in the short run economic growth causes saving.

Bolarinwa and Obembe (2017) examined the nexus between saving and economic growth among the subSaharan African fastest growing African countries of Nigeria, Ghana, Sierra Leone, Burkina Faso, Liberia and Niger between time span of 1981 to 2014, using the recently developed methodologies of ARDL, and Toda and Yamamoto co integration and Granger causality tests. They found that unidirectional causality from economic growth to gross domestic saving for Ghana and Burkina Faso, while gross domestic saving Granger causes economic growth in Liberia, Niger, and Sierra Leone, indicating a unidirectional causality. However, no causality is recorded for Nigeria. But, the existence of a long run relationship between the variables is general among the countries.

\section{Empirical literatures in Ethiopia}

Some empirical studies have been carried out on the nexus between gross domestic savings and economic growth in context of Ethiopia. However, such empirical evidences are mixed depending on the measurement of variables and techniques adopted. These empirical studies on the subject are reviewed and presented as follows: 
Ibrahim (2014) founds that there was unidirectional causality runs from economic growth to savings both in the long run and short run using annual data from 19752013 by employed Johansen co-integration method and the Granger causality test to examine causal relationship between savings and economic growth in Ethiopia.

Mohanty (2017) has examined the direction of causal relationship between gross domestic saving and economic growth in Ethiopia using annual time series data during the period 1975-2016. He employed Johansen Co integration Test to explore the long-run relationship between the series and Vector Error correction (VECM) model and Pair wise Granger Causality Test to perform the causal relationship between domestic savings and economic growth after growth rate of gross domestic savings and the growth rate of real gross domestic product were ascertained using the $\mathrm{ADF}$ unit root test procedure. Finally, he revealed that there was bi-directional causal relationship between growth rate of gross domestic savings and growth rate of GDP both in the short run and long run in Ethiopia indicated that both the Keynes theories and Solow's hypothesis are relevant for Ethiopia. Lambamo (2017) investigated the interplay between savings, inflation and economic growth by applying 2SLS technique within the framework of Simultaneous equation and OLS model using time series data from 1981 to 2015 to estimate the threshold level of inflation that is consistent for the economic growth of Ethiopia. He confirmed that the relationship between domestic saving and economic growth has been found to be one directional and positive. The direction of causality running from economic growth to saving

Getenet (2017) examined the trends and determinants of gross domestic savings (GDS) as economic growth rate was among one of the explanatory variables of gross domestic savings. He employed co-integration and error correction model via annual time series data for the period 1980-2014. The study revealed that economic growth rate was insignificant to boost gross domestic saving but he did not mean that saving was not contributed to economic growth in Ethiopia.

The general observation from the review of literatures on the relationship between savings and economic growth is that the results are mixed depending on the econometric method and measurement of variables and environments where the studies are undertaken. Furthermore, the study observed the following points on the literature. One, empirical studies on the subject is scarce especially in
Sub-Saharan African countries like Ethiopia have not been empirically investigated. Two, apart from Bolarinwa and Obembe (2017) that was conducted on six sub-Saharan African fastest growing economies of Burkina Faso, Ghana, Liberia, Nigeria, Niger and Sierra Leone, there is no study that has employed ARDL methodology and Toda-Yamamoto causality test to revalidate the scanty existing results. Three, Sililo (2010) enquired a directional link between stock market development and economic growth in Zambia for 2002 to 2009. He applied and compared the results of both Granger causality test developed by Granger (1969) as well as the Toda and Yamamoto (1995) causality test methods to investigate the causal relationship and concluded that the results of Toda and Yamamoto method were more reliable. It suggested that the economic growth caused stock market development. In contrast, Granger causality test indicated that economic growth and stock market development were independent of each other. Lastly, it is observed that no attempts have been made in Ethiopia using the methodology of Toda and Yamamoto Granger causality test. Thus, this study undertakes Toda and Yamamoto's causality test for Ethiopia. Hence, this study intends to fill these gaps in the literature.

\section{Materials and Methods}

\section{Sources of Data}

This paper employed annual time series data for the period between 1976 and 2017. Sample time span was selected based on the availability of statistical data. The sources of data were collected from National Bank of Ethiopia (NBE) and Minister of Finance and Economic Cooperation (MoFEC).

\section{Model Specification}

The close relationship between savings and the economic growth has been well specified in a number of empirical investigations (Sinha and Sinha, 1998; Saltz, 1999; Mohanty, 2017) they were derived from the Keynesian hypothesis and the Solow's growth model. The Keynesian hypothesis stated that increase in income leads to a growth in savings. On the contrary, Solow (1956) argued that higher savings precede economic growth. This means that an increase in savings lead to a growth in the economy. Thus in light of the existing literatures, the theoretical model used to examine the relationship between gross domestic savings and economic growth is stated as follows: 
$\Delta L Y t=f((\Delta L Y t-i),(\Delta L S t-i)\}--\cdot-\cdot-\cdot-\cdot-\cdot-\cdot(3.1)$

$\Delta L S t=f((\Delta L Y t-i),(\Delta L t-i)\}$

Where: LYt is the natural logarithm of per capita real GDP used as proxy for economic growth, and LSt natural logarithm of real gross domestic savings; $\Delta$ is the difference operator; $\Delta \mathrm{LYt}-\mathrm{i}$ is lagged values of per capita real GDP and $\Delta \mathrm{LSt}-\mathrm{i}$ is the lagged values of real GDS. In equations (3.1) and (3.2) the lagged values of per capita real GDP and real gross domestic savings respectively are included in the explanatory variables to eliminate the business cycle effect between per capita real GDP and growth rate of gross domestic savings. The linear model for this study is specified in logarithmic form to eliminate or to reduce considerably any Heteroskedasticity in the residuals of the estimated model.

\section{Definition and Measurements of Variables}

\section{Real Gross Domestic Product Per capita (RGDP)}

Real GDP is a macroeconomic measure of the value of economic output adjusted for price changes (i.e. inflation or deflation). This adjustment transforms the money value measures, nominal GDP, into indexes for quantity of total output (Ogbokor, 2016). Although GDP is total output, it is primarily useful because it closely approximates the total spending of the country. Due to inflation, GDP increases and does not actually reflect the true growth in an economy (Ashagrie, 2015). This is why the GDP must be divided by the inflation rate to get the growth of real GDP. Even different organizations use different types of real GDP measures, recently the World Bank switched from 2005 to 2010 constant prices and exchange rate (World Bank, 2015). Hence, this study economic growth is measured by per capita real gross domestic product at constant local currency unit because it is an inflation-adjusted measure that reflects the total value of goods and services produced in a given year and also it takes into consideration the total population of the country. It is expressed as in base-year prices $(2010=100)$. Real gross domestic product per capita growth rate (RGDP) is a proxy for economic growth. This measure provides a high indicative power of the quality and quantity of economic growth (Karimo \& Ogbonna, 2017). Per capita figures are expressed per 1 population. It is argued that an increase in income (economic growth) coupled with sound financial system increases the marginal propensity to save (MPS). Therefore, the expectation of the relationship between economic growth and gross domestic savings is positive.

\section{Gross Domestic Savings}

Gross Domestic Saving is calculated as Gross domestic product (GDP) less final consumption expenditure (total consumption) by government and the private sector (Abu, 2010). This study used Real Gross domestic saving (RGDS) rather than savings ratio as the focus of this study is on the total amount of resources available for capital formation. Besides that, the use of savings ratio may not provide a clear picture of the trend in savings (Saltz, 1999). Romer (1986) explicitly showed that higher rates of savings and hence capital accumulation can trigger a permanent increase in economic growth. Many empirical studies also asserted that high gross domestic saving rate usually indicates a country's high potential to invest. Hence, the exact expected impact of gross domestic savings on economic growth is positive.

\section{Methods of data Analysis and Econometric Estimation Technique}

This paper employs Granger-causality test based on augmented VAR modeling to test the causal relationship between gross domestic savings and economic growth in Ethiopia. In this section, we discussed the details of econometric framework. All computations were performed using E-views 9 window.

\section{Unit root test}

Unit root test is the starting point of time series analysis to determine the order of integration of the variables. When dealing with time series data, it is necessary to assess whether the series is stationary or not. The reason behind is that regression of a non-stationary series on another non-stationary series lead to what is known as spurious regression. Thus, in order to get rid of this abnormality, the unit root test was conducted on each of the variables under study to determine their stationary traits. The presence of unit root indicates that the variables are not stationary. The most common and popular one in econometric work to test the stationarity condition of the time series data is the Augmented Dickey Fuller (ADF) test suggested by Dickey and Fuller (1979) (Gujarati, 2006). The ADF test here consists of estimating the following regression: The starting point of the unit root process is: 
$\mathrm{Yt}=\mathrm{pYt}-1+\mu \mathrm{t},-1 \leq \rho \leq 1-\cdots-(3,7)$

Subtract $\mathrm{Y}_{\mathrm{t}-1}$ from both sides of equation (3.5) to obtain

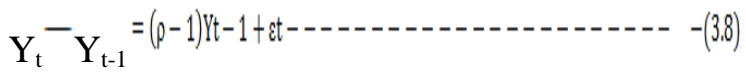

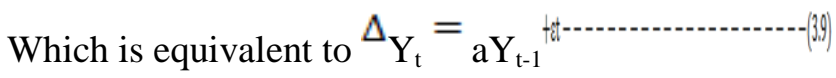

Where: $\alpha=(\rho-1), \varepsilon \sim(0, \delta 2)$, Yt is the variables to be tested for non-stationrity; $t$ is the time trend; and $\Delta_{\text {as }}$ usual is the first difference operator. Estimating equation (3.7) and test the null hypothesis that $\alpha=0$ then $\rho=1$, that is a unit root, meaning the time series under consideration is non stationary. The hypothesis is formulated as follows:

Ho: $\alpha=0$ or $(\rho=1)$

H1: $\alpha<0$ or $(\rho<1)$

\section{Bounds Co-integration Test}

There are various techniques for conducting co integration analysis to determine whether there exists a long run relationship among time series variables. The well-known methods are the residual-based approach proposed by Engle and Granger (1987) and the maximum likelihood-based approach proposed by Johansen and Julius (1990).

The Engle and Granger (1987) estimation results with small samples are biased due to neglecting the short-run dynamic reactions between variables (Banarjee et al., 1993). It is also based on the assumption that a cointegrated vector exists. However, using this method will lead to inefficiency if there is more than one cointegrated vector (Pesaran and Smith, 1998).

To overcome these drawbacks, Johansen (1989) and Johansen and Juselius (1992) suggest maximum likelihood estimation method for convergence tests and co integrated vector derivation. The Johansen-Juselius method may not be useful when model variables have different degrees of stationarity. Thus, this study adopted ARDL model which gives results irrespective of the degree of stationarity of the variables. This technique has certain econometric advantages as compared to other co integration procedures. First, it is applicable irrespective of the degree of integration of the variables (i.e. whether the underling variables are purely I (0), I (1) or mixture of both) and thus avoids the pretesting of the order of integration of the variables. Second, the long-run and short-run parameters of the models are estimated simultaneously. Third, the ARDL approach is more robust and performs better for small sample sizes whereas the Johansen techniques require large data sample, a luxury that most developing economies do not have (Ghatak and Siddiki, 2001). The ARDL model used in this study can be introduced as follows:

$\Delta L Y t=a 0+\sum_{i=1}^{m} \beta i L L Y t-i+\sum_{i=0}^{m} p i \Delta L S t-i+\delta 1$ iLt $-1+\delta 2 L S t-1++\varepsilon 1 t----(3,10)$

$\Delta L S t=a 1+\sum_{i=1}^{m} \varphi i \Delta L Y t-i+\sum_{i=0}^{m}$ OidLSt-i $+a 1 L Y t-1+a 2 L S t-1+\varepsilon 2 t----(3,11)$

Where: ${ }^{\varepsilon 1 \mathrm{t}}$ and ${ }^{\varepsilon 2 \mathrm{t}}$ are the disturbance terms; " $\mathrm{m}$ " is lag length for the unrestricted error-correction model (UECM).

The first part of equations (3.10) - (3.11) with ${ }^{\beta \mathrm{i}},{ }^{\mathrm{\gamma} \mathrm{i}}$, and $\varphi \mathrm{i}, \vartheta \mathrm{i}$, represents the short run dynamics of the models and the second part $\delta 1$ and $\delta 2$ and $\alpha 1$ and $\alpha 2$ corresponds to the long-run relationship. The null hypothesis in the first equation (3.10) is Ho: ${ }^{\delta 1}=\delta 2=0$, which means the non-existence of a long-run relationship against the alternative $\mathrm{H} 1$ : $\delta 1 \neq \delta 2 \neq 0$ meaning that there is a long-run relationship. In the second equation (3.11), the null is $\mathrm{H} 0:{ }^{\alpha 1}=\alpha 2=0$ against the alternative $\mathrm{H} 1$ : $\alpha 1 \neq \alpha 2 \neq 0$ which states that we have co integration. From equation (3.10) and (3.11), we first test the null hypothesis of no co integration against the alternative hypothesis using the F- test with upper and lower after the ARDL regression estimates. To investigate the presence of long run relationships among the variables bound test under Pesaran et al., (2001) is used which is based on the F-test. The calculated F-statistic is compared with the critical value tabulated by Pesaran et al., (2001). The null hypothesis of no co integration will be rejected if the calculated F-statistic is greater than the upper bound. To this end, the order of the lag distribution function should be selected using one of the standard information criteria such as Akaike Information Criteria (AIC) and Schwartz Bayesian Criterion (SBC). 
The next step is to estimate the short-run error correction model obtained from the ARDL model to capture the short run dynamics of the model (adjustment parameters that measure the speed of correction to long-run equilibrium after a short-run disturbance). The standard ECM is estimated as follows:

$\Delta L Y t=\partial 0+\sum_{i=1}^{m} \beta i \Delta L Y t-i+\sum_{i=0}^{m} \gamma i L L S t-i+\lambda 1$ ECMt $-1+e t 1--------(3.12)$

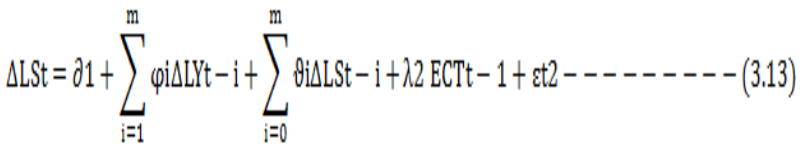

Where: ECTt-1 is error correction term lagged by one time period that must be negative, $\lambda 1$ and $\lambda 2$ are the speed of adjustment to the equilibrium after a shock. The coefficients ${ }^{\beta \mathrm{i}}$ and ${ }^{\gamma \mathrm{i}}$ are the coefficients for the shortrun dynamics of the model's convergence to equilibrium, $\varepsilon 1 \mathrm{t}$ and ${ }^{\varepsilon 2 \mathrm{t}}$ are the error terms. The existence of an error correction term among a number of co integrated variables implies that changes in the dependent variable are a function of both the level of disequilibrium in the co integration relationship (represented by the ECT) and the changes in other explanatory variables. This tells us that any deviations from the long run equilibrium will feed back on the changes in the dependent variable in order to force the movement towards the long run equilibrium.

\section{Toda and Yamamoto Approach to Granger Causality Test}

The most commonly used methodology in investigating the causal relationship among time series variables is what is referred to as the standard Granger Causality Test developed by Granger (1969). This Causality test approach is easy to carry out and be able to apply in many kinds of empirical studies. However, it has limitations.

Firstly, the direction of the causality depends on the number of lags chosen. If the lag of choice is different from the real lag, the results of the model become biased or inefficient (Gujarati, 2006). The biggest problem here is how does one know what the 'true' or optimal lag is? There are statistical tools available for choosing optimal lag length, but depending on the choice of criterion, one can end up with a lag length that is not optimal lag. This in a way creates some subjectivity. Another element of subjectivity comes when one has to choose a maximum lag from which an optimal lag is chosen. The second criticism of this Causality Test approach is the stationarity of variables problem. When variables are stationary they move together in the long run or trend together. If the variables are not stationary and are used in the Test, the regression results might be misleading (Wooldridge, 2001). Therefore, in order to use the Granger Causality Test one would have to test the variables being used for stationarity. These required pretests can cause distortions resulting in the Granger Causality test to suffer from 'low power'. Moreover, when a series is found to be non-stationary, in order to make it stationary, the first difference is taken and this process results in loss of long-run information then pretests should be avoided (Hacker and Hatemi, 2006).

In dealing with these problems, this study adopts a different procedure developed by Toda and Yamamoto (1995) that utilizes a modified Wald test for restrictions on the parameters of a VAR $(\mathrm{k})$ model (where $\mathrm{k}$ is the lag length in the system). Toda and Yamamoto (1995) proved that this test has an asymptotic $\chi_{2}$ distribution when a VAR ( $\mathrm{k}+\mathrm{d}$ max) model is estimated (where $\mathrm{d}$ max is the maximal order of integration suspected to occur in the system). The advantage of this procedure is that it does not require knowledge of co integration properties of the system. This test can be done even if there is no co integration and/or the stability and rank conditions are not satisfied (Zapta and Rambaldi, 1997). The study test for the Toda-Yamamoto Granger Causality test based on the following equations:

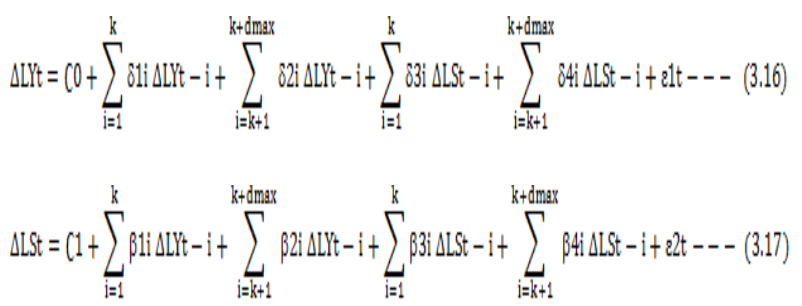

Where, ${ }^{\delta i}$ and $\beta i$ are parameters of the model; $k$ is the optimal lag length; ${ }^{\varepsilon 1 t}$ and $\varepsilon 2 \mathrm{t}$ are the residuals of the model; L represents natural logarithm. From equation (3.16), the null hypothesis, $H 0: \delta 3 \mathrm{i}=0$ is a test that LSt do not granger-cause LYt. Similarly, equation (3.17) the null hypothesis, $H 0: \beta 3 \mathrm{i}=0$ means LYt do not grangercause LSt. Then, the Granger causality is tested using the modified Wald (MWald) test, as it involves estimation of 
a VAR augmented model. The computed Wald-statistic has an asymptotic chi-square distribution with $\mathrm{k}$ degrees of freedom. Rambaldi and Doran (1996) have shown that the MWald tests for testing Granger no-causality experience efficiency improvement when Seemingly Unrelated Regression (SUR) models are used in the estimation.

\section{Results and Discussion}

\section{Unit root test Result}

The empirical results commence by testing the order of integration of the variables. The Augmented Dickey Fuller test approach was employed. The test indicates that RGDS is stationary in their levels form because the computed absolute values of the tau statistics $\left({ }^{\tau}\right)$ exceed the ADF (or MacKinnon, 1996) critical tau values, implying that the null hypothesis $(\delta=0)$ of a unit root was rejected for these variables. But, real GDP is nonstationary in level form since their ADF values are less than the critical values; the null hypothesis of a unit root was accepted for real GDP, but rejected in 1st difference.

Table 4.1 obviously reveals that the variables are a combination of $\mathrm{I}(0)$ and $\mathrm{I}(1)$ variables. Such results of stationarity test would not allow us to apply the Johansen approach of co-integration. Thus, the ARDL approach popularized by (Pesaran et al., 2001) is most suitable for this study. The unit root test shows that the maximum order of integration is one. Hence, augmented VAR models was add only one extra lag (i.e. dmax $=1$ ) with the appropriate lag length for the implementation of the causality test. The optimal lag lengths for the variables in the VAR, $\left(\mathrm{k}^{*}\right)$, is selected based on the usual information criteria, such as Akaike and Schwarz Information Criteria. In table 4.4 indicates that the appropriate lag length criteria for the VAR model is one that minimize Akaike Information Criterion (AIC), Schwarz Information Criterion (SIC), Final Prediction Error (FPE) and Hannan-Quinn Information Criterion (HQ) which is the bolded row in table 4.2.

\section{Bounds Test for Long-run Relationship}

After conducting unit root test the next important step is the bound test for co-integration. It is used to examine if there exist the long-run relationship among the variables. Co-integration of the variables shows the movement of the variables together due to a certain long run equilibrium relationships. The ARDL bound test approach in testing the existence of the co integrating relationship is applied by comparing the F-statistics with the bound critical values of Pesaran, Shin, and Smith (2001). The null hypothesis of no co-integration will be rejected if the calculated F-statistic is greater than the upper bound critical value. If the computed F-statistics is less than the lower bound critical value, then we cannot reject the null hypothesis. The result is inconclusive if the computed F-statistic falls within the lower and upper bound critical values. The Akaike information criterion (SBC) was used in the co-integration analysis.

The empirical result rejects the null hypothesis of no long-run relationship between gross domestic saving and economic growth using both LRGDSt and LRGDPt as a dependent variable, the results show that there is a longrun relationship from the $\log$ of real gross domestic saving to $\log$ of real gross domestic product and from log of real gross domestic product to $\log$ of real gross domestic saving in Ethiopia (Table 4.3). Because the calculated F- statistics for Model 1 and Model 2 is 5.84 and 14.68 respectively, this is greater than the upper and lower bounds at 1 percent significance level. The estimated ARDL model and the regression result for both LRGDP and LRGDS models are presented below.

\section{Short run Error Correction estimates}

After the acceptance of long-run coefficients of the model, the short-run ECM model is estimated. The error correction term indicates the speed of the adjustment which restores equilibrium in the dynamic model. The ECM coefficient shows how quickly variables return to equilibrium and it should have a statistically significant coefficient with a negative sign and statistically significant at a standard significant level (i.e. p>0.05). Banerjee et al., (2003) holds that a highly significant error correction term is further proof of the existence of a stable long-term relationship.

The table 4.4 above shows that the result of the ECT 0.726 (or $72.6 \%$ ) and $-0.421(42 \%)$, which measures the adjustment to restore equilibrium in both models respectively, appear with negative sign and is statistically significant at $1 \%$ level of significance level, ensuring the long run equilibrium can be attained. Therefore, the speed of adjustment is -0.726 and -0.421 , which implies that around $72.6 \%$ and $42 \%$ deviations from long-term equilibrium are adjusted every year for each models respectively. This shows that there is quick and high speed of adjustment to equilibrium in case of 
disequilibrium from the long-run path in a year, i.e. the speed of adjustment is relatively high.

\section{Toda and Yamamoto Granger Causality Test Result}

One of the objectives this study is to examine the causal relationship between gross domestic savings and economic growth in Ethiopia. The causal relationship between gross domestic savings and economic growth is estimated by carrying out Block Exogeneity Wald test. The estimates of MWALD test show that the test result follows the chi-square distribution with 2 degrees of freedom in accordance with the appropriate lag length along with their associated probability. The Wald test results are presented in Table 4.5 below.

As explained by the significance of the $p$-values of the modified Wald statistic, the study reports unidirectional causality runs from economic growth to gross domestic saving because the estimated Chi-sq $\left(\chi^{2}\right)$ is statistically significant at the $5 \%$ level of significance $(0.026<$ $0.05)$, meaning that past values of economic growth have predictive power in determining the present values of gross domestic saving. This means that economic growth granger causes gross domestic saving in Ethiopia for the period from 1976 to 2017. This is the viewpoint of the Keynesian hypothesis which believes that economic growth leads to saving. However, no other significant causal effects are identified because the estimated Chi-sq $(\chi 2)$

value is statistically not significant $(p>0.05)$. The result is confirmed by the existing work of Ibrahim (2014) and Lambamo (2017) found that unidirectional causality running from economic growth to gross domestic savings in the case of Ethiopia. The finding is also consistent with other studies carried out by Michael and Emmanuel (2016) for Nigeria, Bolarinwa and Obembe (2017) for Ghana and Burkina Faso, and Patra et al., (2017 for Indian they reported unidirectional causality running from economic growth to gross domestic saving. However, the result of this study contradicts with the conventional wisdom that saving is the cause of economic growth (Solow, 1956). This study contrasts with the studies like Mohanty (2017) found bidirectional causality running from gross domestic saving to economic growth and vice versa in Ethiopia which employ ordinary Granger causality technique. This study is also inconsistent with works of Pickson et al., (2017) for Ghana and Bolarinwa and Obembe (2017) for Sierra Leone, Niger and Liberia that reported unidirectional causality runs from gross domestic saving to economic growth. However, the existence of the long- run relationship reported by ARDL technique employed in the study confirms the findings of the above-existing studies that employ Johansen co integration method to test for the long-run relationship.

The absence of causal relationship from gross domestic savings to economic growth appears to be at odd with the popular perception that raised an important issue regarding the appropriateness of using domestic saving as a target variable for economic progress; because the author did not find enough evidence to show that the causal direction runs from gross domestic savings to economic growth in Ethiopia. Because it may be due to reasons that cause saving to be unproductive to growth or there may be some other factors that contribute to economic growth in this country instead of saving. This implies that the conventional wisdom that higher level of saving leads to economic growth is not likely to hold in Ethiopia. It is also the reason that level of real gross domestic savings per capita is so small in this country because of the present unemployment problem in Ethiopia is alarming and this is having a great consequence on gross domestic saving of the people; that's why saving is an outcome of increase in per capita income and people will only save when they have income (Keynes, 1936). Therefore, it cannot be an important cause of growth. This indicates that economic growth in Ethiopia may be the cause of other variables other than saving. Thus, this is the reason why the empirical result suggests that domestic saving does not granger cause to economic growth in Ethiopia.

From the result that gross domestic saving does not granger cause to economic growth in Ethiopia was supported by the information which was stated in the introduction part about the problem from high gap of gross domestic saving and investment. Ethiopia did not have enough domestic saving to serve for demand of investment. Even though domestic savings as a percentage of GDP rose from $15 \%$ in 1975 to $22.4 \%$ in $2015 / 16$, it was still insufficient to be a source of finance for domestic investment, which increased from $19 \%$ in 1975 to $39 \%$ in $2015 / 16$. There was a large gap of saving and investment of 15 percent of GDP in 2015/16 (MoFEC, 2016). Therefore, lot external saving come to absorb the insufficiency of internal saving. From the combining of internal and external saving could help to create investments which lead to economic growth in Ethiopia. Foreign direct investments could bring technological progress and innovation into the country which might be a factor to create economic growth for Ethiopia. 
Table.1 ADF Unit Root Test Result for original Series (level)

\begin{tabular}{l|l|l|l|l}
\hline Variables & Only Constant & with trend \& constant & without intercept \& trend & $\begin{array}{l}\text { Integratio } \\
n \text { order }\end{array}$ \\
\cline { 2 - 5 } & Test Statistics & Test Statistics & Test Statistics & - \\
\hline LRGD & -1.854883 & -6.445736 & -0.581273 & I $(1)$ \\
L(LRGD) & $-4.937238 * * *$ & $-4.863516 * * *$ & $-10.52944 * * *$ & $\mathrm{I}(0)$ \\
$\Delta($ LRGDS) & $-8.522209 * * *$ & $-8.666149 * * *$ & $-7.430714 * * *$ & - \\
Critical values at 1\% & -5.975345 & -5.870179 & -5.978079 & \\
Critical values at 5\% & -3.600987 & -4.198503 & -2.622585 & \\
Critical values at 10\% & -2.935001 & -3.523623 & -1.949097 & \\
\hline
\end{tabular}

Source: Author's Computation. Note: The rejection of the null hypothesis is based on MacKinnon (1996) critical values. Akaike information criterion (AIC) is used to determine the lag length while testing the stationarity of all variables. The ***, ** and * represent the rejection of the null hypothesis of non-stationary at $1 \%, 5 \%$ and $10 \%$ significant level respectively.

Table.2 Selection of the order of the VARs $\left(\mathrm{k}^{*}\right)$

\begin{tabular}{lllllll}
\hline Lag & LogL & LR & FPE & AIC & SC & HQ \\
\hline 0 & -390.3565 & NA & 7129.140 & 20.22341 & 20.39403 & 20.28463 \\
$\mathbf{1}$ & $\mathbf{- 3 4 9 . 4 6 4 9}$ & $\mathbf{7 1 . 2 9 8 1 2} *$ & $\mathbf{2 0 0 0 . 3 6 6 *}$ & $\mathbf{1 8 . 9 4 6 9 2} *$ & $\mathbf{1 9 . 8 0 0 0 3 *}$ & $\mathbf{1 9 . 2 5 3 0 1 *}$ \\
2 & -335.6843 & 21.20093 & 2305.576 & 19.06073 & 20.59633 & 19.61169 \\
3 & -321.9847 & 18.26607 & 2788.108 & 19.17870 & 21.39679 & 19.97453 \\
\hline
\end{tabular}

* indicates lag order selected by the criterion. LR: sequential modified LR test statistic (each test at 5\% level). FPE: Final prediction error. AIC: Akaike information criterion. SC: Schwarz information criterion. HQ: Hannan-Quinn information criterion

Table.3 ARDL Bound Test for gross Domestic Savings and Economic growth

\begin{tabular}{c|c|c|c|c}
\hline \multirow{2}{*}{$\begin{array}{c}\text { Significance } \\
\text { level }\end{array}$} & \multicolumn{2}{|c|}{ Model 1: Real GDP } & \multicolumn{2}{c}{ Model 2: Real GDS } \\
\cline { 2 - 5 } & \multicolumn{2}{|c|}{ Critical Value bounds for $\mathrm{k}=3$} & \multicolumn{2}{c}{ Critical Value bounds for $\mathrm{k}=3$} \\
\cline { 2 - 5 } & Lower bound I(0) & Upper bound I(1) & Lower bound I(0) & Upper bound I(1) \\
\hline 1 percent & 3.65 & 4.66 & 3.65 & 4.66 \\
5 percent & 2.79 & 3.67 & 2.79 & 3.67 \\
10 percent & 2.37 & 3.2 & 2.37 & 3.2 \\
\hline$F$ - statistics & \multicolumn{2}{|c|}{$F$-statistics $=5.841853^{* * *}$} & \multicolumn{2}{|c}{$F$-statistics $=14.68721^{* * *}$} \\
\hline
\end{tabular}

Source: Authors' estimation using ARDL Bounds Test. $\mathrm{K}$ is the number of non-deterministic repressors' in the long run relationship Critical values from Pesaran, Shin, and Smith (2001).

Table.4 Short run Error Correction estimates

\begin{tabular}{llll|lll}
\hline \multicolumn{3}{l}{ Model 1: Dependant Variable is D(LRGDP) } & \multicolumn{3}{l}{ Model 2: Dependant Variable is D(LRGDS) } \\
\hline Variable & Coefficient & t-Statistic & Prob. & Coefficient & t-Statistic & Prob. \\
\hline D(LRGDS/P) & $4.57318^{* * *}$ & 3.10101 & 0.0039 & $0.05121 * * *$ & 3.84242 & 0.0005 \\
ECT(-1) & $-0.72647 * * *$ & -5.00447 & 0.0000 & $-0.42064 * * *$ & -10.5765 & 0.0000 \\
\hline
\end{tabular}

Source: Authors computation. Note: *** represents significance level at $1 \%$ 
Table.5 Block Exogeneity Wald Tests

\begin{tabular}{llll}
\hline Null Hypothesis & Chi-sq $\left(\chi^{\mathbf{2}}\right)$ & Prob. & Decision \\
\hline RGDP does not Granger cause RGDS & $14.33005^{* * *}$ & 0.0262 & Reject Ho \\
RGDS does not Granger cause RGDP & 6.150466 & 0.4065 & Do not Reject Ho \\
\hline
\end{tabular}

Source: Authors computation. **represents significance level at 5 percent; Notes: The reported estimates are asymptotic Wald statistics. The $[\mathrm{k}+\mathrm{m}]^{\text {th }}$ order level VAR is estimated with maximal order of integration (m) being.

Table.6 Diagnostics Tests

\begin{tabular}{|c|c|c|c|c|}
\hline \multicolumn{3}{|c|}{ Model 1: Dependant variable is $\Delta \mathrm{LYt}$} & \multicolumn{2}{|c|}{ Model 2: Dependant variable is $\Delta \mathrm{LSt}$} \\
\hline Test Statistics & Chi-Square & Prob. & Chi-Square & Prob. \\
\hline Autocorrelation test & 0.9593 & 0.9690 & 0.8013 & 0.8314 \\
\hline Heteroskedasticity test & 0.8135 & 0.8507 & 0.0691 & 0.0659 \\
\hline Normality test (J-B) & 0.3144 & 0.8541 & 0.1551 & 0.9253 \\
\hline Functional Form test & $F(1,32)=0.3869$ & 0.5383 & $F(1,35)=3.262$ & 0.0795 \\
\hline \multirow{2}{*}{$\begin{aligned} & \text { Stability Test* CUMSUM } \text { CUMSUMSQ } \\
& \text { CUMSUM }\end{aligned}$} & \multicolumn{2}{|l|}{ Stable } & \multicolumn{2}{|c|}{ Stable } \\
\hline & \multicolumn{2}{|l|}{ Stable } & \multicolumn{2}{|c|}{ Stable } \\
\hline
\end{tabular}

Source: Authors' estimation. Notes: Autocorrelation test is the residual serial correlation LM test. Normality test is the residual normality test of Jarque-Bera statistics. Heteroskedasticity test is the test for residual Heteroskedasticity tests. Functional Form test is Ramsey RESET Test of F-statistic. * denotes the cumulative sum of recursive residuals See plot in figure 4.1 and 4.2.

Fig.1 Plot of Cumulative sum of recursive residuals for Economic Growth

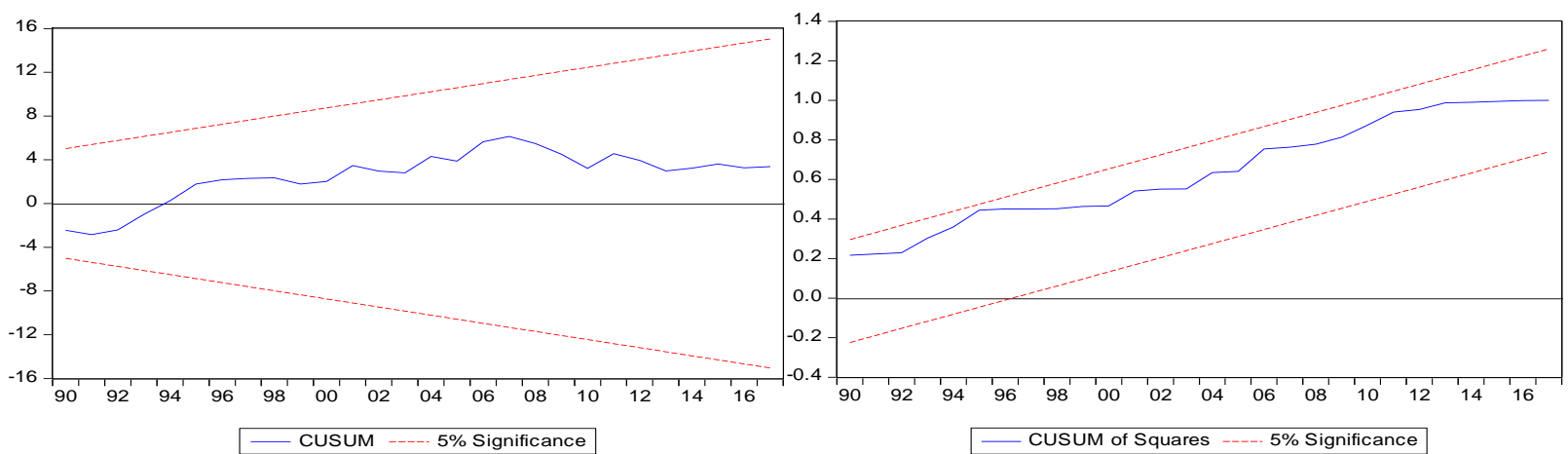

Source: Author Calculations. Note: The straight lines represent critical bounds at 5\% significance level

Fig.2 Plot of Cumulative sum of recursive residuals for Savings Model

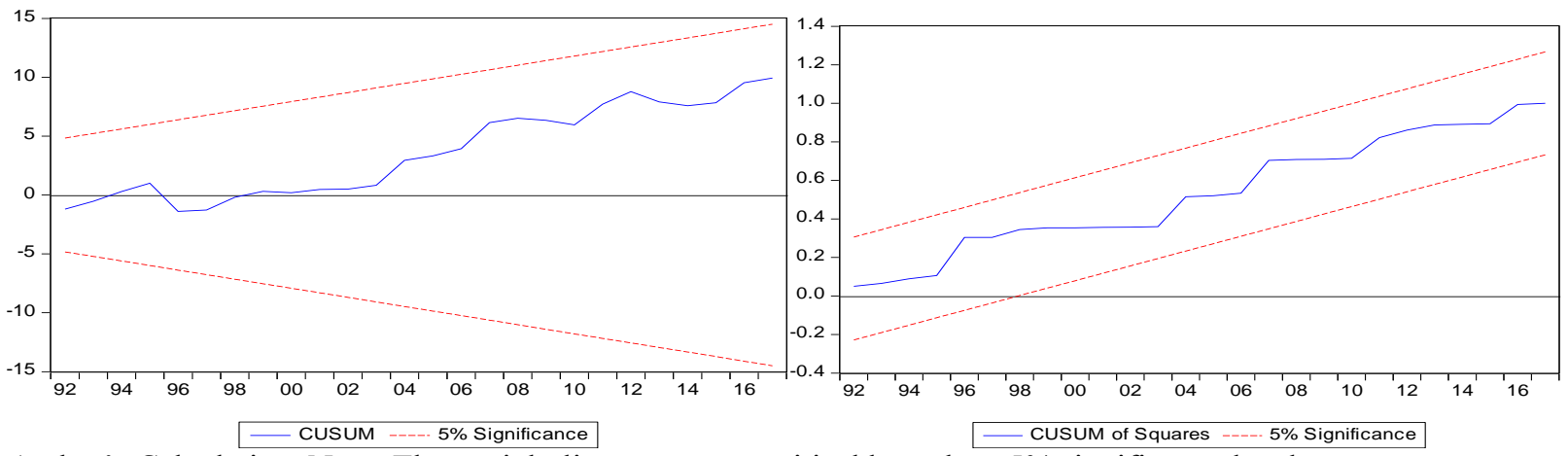

Source: Author's Calculation. Note: The straight lines represent critical bounds at 5\% significance level. 
For all these situation stated above, we can say that in the case study of Ethiopia the rate of economic growth tend to lead to the rate of domestic saving rather than the changing of domestic saving cause the changing in economic growth.

\section{Model Stability and Diagnostic Test}

In order to establish the validity of the estimates, a number of diagnostic tests including the BreuschGodfrey serial correlation LM test, Jarque-Bera normality test, the Ramsey reset for model specification and $\mathrm{ARCH}$ test for heteroskedasticity are carried out. In order to reject or accept the null hypothesis, we can decide by looking the p-values associated with the test statistics. That is the null hypothesis is rejected when the p-value are smaller than the standard significance level (i.e. 5\%). From the results of the diagnostic tests, the estimated residuals of equations are shown to be normal given the Jacque-Bera statistic 0.431 with a probability value of (0.806). Breusch-Godfrey serial correlation LM test statistic indicates that the estimates are free from serial correlation. The homoscedastic nature of the residuals is confirmed by the ARCH test statistic of 0.382 with a probability value of (0.883). Ramsey Reset test ascertains whether the correct functional form of the equation is used. The test statistic of 0.548 and the probability of $(0.655)$ suggest that the correct functional forms have been used. Such tests are recommended by Pesaran et al., (2001).

In addition to the above diagnostic tests, the stability of long run estimates has been tested by applying the cumulative sum of recursive residuals (CUSUM) and the cumulative sum of squares of recursive residuals (CUSUMSQ) test. The test statistics is graphed in figure 4.1 and 4.2. The graph shows that the models are stable within 5 percent significance level since the plot of CUSUM and CUSUMSQ statistic moves between the critical bounds (at 5\% significance level), then the estimated coefficients are said to be stable. It can also identify not only their significance but also at what point of time a possible instability (structural break) occurred. The graph also shows a possible instability or structural breaks within the given periods. As can be seen from the first figure, the plot of CUSUM test did not cross the critical limits. Similarly, the CUSUMSQ test shows that the graphs do not cross the lower and upper critical limits. So, we can conclude that long and short runs estimates are stable and there is no any structural break. Hence the results of the estimated model are reliable and efficient.
Based on the findings of this study, the researchers came to the conclusion that a stable long relationship exists between savings and economic growth in Ethiopia. The causal empirical results revealed that the growth rate of real GDP per capita Granger cause real gross domestic saving in Ethiopia. This can be concluded that Ethiopia tends to have higher level of income (RGDP) first in order to generate higher rate of domestic saving. The outcome of this paper is relevant for development policy, since economic growth is often a key focus. The policy implication of this result is that economic growth is considered as the policy variable to accelerate gross domestic saving in the economy. Although the paper found growth leads to saving, it doesn't necessarily mean that saving doesn't contribute anything to growth. In fact, growth theory suggests that saving plays crucial role in promoting economic growth. Therefore, the ongoing effort by the government to enhance saving should also be encouraged as one of the means that leads to the road to growth and development.

To this end, we recommend that government and policy makers should focus on income policies that would accelerate economic growth so as to increase saving. These include among others the following. Firstly, government should increase its investment in the provision of infrastructural facilities like power, roads, education, health, research and development, and among others. This will help to reduce the costs of doing business as well as increase the profitability of firms, thereby raising the economy's production of goods and services. The third policy implication is that, since inflation has adverse effects, they should be kept at the level that cannot cause adverse effects on saving behavior. The third policy implication is that there is a need to urgently develop the financial sector of the country by further expanding bank branches and services and by creating a very competitive environment in the financial sector. The study also recommends that the government should influence the commercial banks to reduce their lending rate so that prospective investors can increase their investment and raise the nation's production capacity. At the same time the government should increasing their deposit rate at least above the rate of inflation through monetary policy at the disposal of the National bank. These practices increase savings and growth in the economy at the same time. Alternatively, the government should use expansionary fiscal policy which is increasing government spending and decreasing taxes would mean that aggregate demand would increase to boost output in the economy. This will automatically increase gross domestic saving in these countries. And 
consequently, increase in gross domestic saving will also lead to increase in capital formation and investment. This will finally improve the general welfare of the people. So, the government should adopt an appropriate approach in either way to foster economic growth and encourage savings.

Lastly, this study has attempted to come up with the result of the analysis with defined scope however a lot remained to be unanswered. Future research is needed to find out what are other factors that would enhance economic growth in Ethiopia, by taking into account more factors, not only savings. This study utilized annual data, if conducted the study by using the quarterly data, the empirical result would be more accurate. The other main factors such as FDI or external saving which state in causality empirical part might be perform as the main variables of economic growth. Of course this is beyond the scope of this paper, but this is open another agenda for future research.

\section{Acknowledgement}

I appreciate and acknowledge the comments and suggestions from Dr Zelalem Ejigu, I would like to take this opportunity to express my profound gratitude and deep regard his valuable suggestions and further I thank my colleagues at Development Bank of Ethiopia, Nekemte branch for their valuable suggestions and moral support.

\section{Conflicts of Interest}

The author declares that there is no conflict of interest regarding to the publication of this paper.

\section{References}

(2016). Annual Progress Report for F.Y. 2015/16. Addis Ababa: MoFEC.

Abu, N. (2010). Saving-Economic Growth Nexus in Nigeria, 1970-2007: Granger Causality and CoIntegration Analyses. Review of Economic and Business Studies, 3 (1).

Agrawal, P. (2001). The Relation between Savings and Growth: Cointegration and Causality Evidence from Asia. Applied Economics, 23.

Ashagrie, D. (2015). Inflation - Growth Nexus in Ethiopia: Evidence from Threshold Auto Regressive Model. Ethiopian Journal of Economics, XXIV, 130.
Banerjee, A., Dolado, J., Galbraith, J. W., \& Hendry, D. (1993). Co-integration, Error-Correction, and the Econometric Analysis of Non-Stationary Data, Advanced Texts in Econometrics. Oxford, UK: Oxford University Press.

Bolarinwa, S. T., \& Obembe, O. B. (2017). Empirical Analysis of the Nexus between Saving and Economic Growth in Selected African Countries (1981-2014). Journal of Development Policy and Practice, 2 (1), 110-129.

Carroll, C. \& Weil. (1994). Saving and Growth: A Reinterpretation. Carnegie-Rochester Conference Series on Public Policy, (pp. 133-92).

Dickey, D. A., \& Fuller, W. A. (1979). Distribution of the estimators for autoregressive time series with a unit root. Journal of the American statistical association, 427-431.

Domar, E. D. (1946). Capital expansion, rate of growth, and employment. Econometrica, 14, 137-147.

Edeme, R. K., \& Ifelunini, I. (2015). Savings, Inflation and Economic growth Linkages: A Re-examination with Nigeria data. Journal of Investment and Management, 4 (5), 180-185.

Engle, R. F., \& Granger, W. J. (1987). Co-integration and error correction: representation, estimation, and testing. Econometrica, 55 (2), 251-276.

Getenet, G. (2017). Trends and Determinants of Gross Domestic Saving in Ethiopia. Journal of Economics and Sustainable Development, 8 (5), 72-80.

Ghatak, S., \& Siddiki, J. (2001). The use of ARDL approach in estimating virtual exchange rates in India. Journal of Applied Statistics, 11, 573-583.

Granger, C. W. (1969). Investigating causal relations by econometric models and cross spectial methods. Econometrica, 37 (3), 424-438.

Granger, C., \& Newbold, P. (1974). Spurious Regression in Econometrics. Journal of Econometrics, 11-120.

Gujarati, D. (2006). Essential of Econometrics (3rd Edition ed.). McGraw Hill.

Hacker, S., \& Hatemi, A. (2006). Tests for causality between integrated variables using asymptotic and bootstrap distributions: theory and application. Applied Economics, 1489-1500.

Haile, A. A. (2013). Determinants of domestic saving in Ethiopia: An autoregressive distributed lag (ARDL) bounds testing approach. Journal of Economics and International Finance, 5 (6), 248-257.

Harrod, R. (1939). An essay in dynamic theory. Economic Journal, 49, 14-33.

Hashmi, N. I., \& Sedai, A. K. (2016). DOMESTIC SAVINGS AND ECONOMIC GROWTH IN INDIA. I J A B E R, 14, 2119-2127. 
Ibrahim, F. (2014). Saving-Growth Nexus in Ethiopia. (N. B. Ethiopia, Ed.) BIRRITU, pp. 8-19.

Jagadeesh, D. (2015). The Impact of Savings on Economic Growth: An Empirical Study Based on Botswana. International Journal of Research in Business Studies and Management, 2 (19), 10-21.

Johansen, S. \&. (1990). Maximum likelihood estimation and inference on cointegration with applications to the demand for money. Oxford Bulletin of Economics and Statistics, 52 (2), 169-210.

Johansen, S., \& Juselius, K. (1992). Testing Structural Hypothesis in a Multivariate Co-Integration Analysis of the PPP and UIP for UK. Journal of Econometrics, 53, $211-244$.

Karimo, T. M., \& Ogbonna, O. E. (2017). Financial Deepening and Economic Growth Nexus in Nigeria: Supply-Leading or Demand-Following? Economies, $5(4), 1-18$.

Kasidi, F., \& Mwakanemela, K. (2013). Impact of inflation on economic growth: a case study of tanzania. Asian Journal of Empirical Research, 3 (4), 363-380.

Keynes, J. M. (1936). The General Theory of Employment Interest and Money. Macmillan Cambridge university press, for royal economic society.

Lambamo, A. G. (2017). Inter-Play Between Saving, Inflation and Economic Growth in Ethiopia: Linkage and Threshold Analysis. Global Journal of HUMAN-SOCIAL SCIENCE: Economics, 17 (4), 19.

Lewis, A. (1954). Economic Development with Unlimited Supplies of Labour. The Manchester School.

Lucas, R. (1988). On the Mechanics of Economic and Development. Journal of Monetary Economics, 22, 3- 42.

McKinnon, R. I. (1973). Money and Capital in Economic Development. Washington, DC: The Brookings Institution.

Michael, E. O., \& Emmanuel, N. (2016). Granger Causality between Private Domestic Savings and Economic Growth in Nigeria: Toda-Yamamoto Approach. Journal of Economics and Sustainable Development, 7, 71-80.

Ministry of Finance and Economic Cooperation (MoFEC). (2015). Growth and Transformation Plan (GTP) 2015/16-2019/20 Draft. Addis Ababa: Ministry of Finance and Economic Development (MoFED).

Modigliani, F. (1970). The Life-Cycle Hypothesis of Savings and Intercountry Differences in the Saving
Ratio, in: W.A. Eltis, M.F.G. Scott, J.N. Wolfe (Eds), "Induction, Growth, and Trade: Essays in Honour of Sir Roy Harrod. Oxford: Oxford University Press.

Mohanty, A. K. (2017). Does Domestic Saving Cause Economic Growth? Time-Series Evidence from Ethiopia. International Journal of Management, IT \& Engineering, 7 (10), 237-254.

Muhammad, S., \& Rana Ejaz, A. K. (2010). Old Wine in New Bottles: Saving - Growth Nexus: Innovative Accounting Technique in Pakistan. Theoretical and Applied Economics, XVII, 49-60.

Odionye, J. C., \& Ugwuegbe, U. (2016). Savings and Economic Growth Nexus: Evidence from Nigeria. Developing Country Studies, 6, 112-120.

Ogbokor, C. A. (2016). ECONOMETRIC ANALYSIS OF THE IMPACT OF FOREIGN DIRECT INVESTMENT ON ECONOMIC GROWTH IN NAMIBIA: EVIDENCE FROM ANNUAL DATA. INTERNATIONAL JOURNAL OF ECONOMICS AND FINANCE STUDIES, 8 (2), 205-2018.

Patra, S. K., Murthyb, D. S., Kuruvac, M. B., \& Mohanty, A. (2017). Revisiting the causal nexus between savings and economic growth in India: An empirical analysis. ECONOMIA, http://dx.doi.org/10.1016/j.econ.2017.05.001, 1-12.

Pesaran, M. H., \& Smith, R. (1998). Structural Analysis of Co-Integration VARs. Journal of Economic Surveys, 12, 471-505.

Pesaran, M. H., Shin, Y., \& Smith, R. J. (2001). Bounds testing approaches to the analysis of level relationships. Journal of Applied Econometrics, 16 (3), 289-326.

Pickson, R., Enning, K., \& Siaw, A. (2017). SavingsGrowth Nexus in Ghana: Cointegration and Causal Relationship Analyses. Theoretical Economics Letters, 7, 139-153.

Rambaldi, A. N., \& Doran, H. E. (1996). Testing for granger non-causality in cointegrated systems made easy. England: Working Papers in Econometrics and Applied Statistics, Department of Econometrics, The University of New England.

Romer, P. (1986). Increasing Returns and Long-Run Growth. Journal of Political Economy, 94, 10021037.

Saltz, I. S. (1999). An Examination of the Causal Relationship between Savings and Growth in the Third World. Journal of Economics and Finance, 23.

Sililo, M. (2010). Stock market development and economic growth: A case for Zambia. Retrieved on $\begin{array}{llll}\text { February } & 15, & 2017 & \text { from }\end{array}$ 
https://scholar.sun.ac.za/bitstream/handle/10019.../s ililo_stock_2010.pdf.

Sinha, D., \& Sinha, T. (1998). Cart before the Horse? The Saving-Growth Nexus in Mexico. Economics Letters, 61.

Solow, R. M. (1956). A contribution to the theory of economic growth. Quarterly Journal of Economics, 70, 65-94.

Tang, C. F., \& Tan, B. E. (2014). A revalidation of the savings-growth nexus in Pakistan. Economic Modeling, 36 (2), 370-377.

World Bank. (2015). World Development Indicator. World Bank.

\section{How to cite this article:}

Zelalem Adugnaw Welela. 2018. Analysis of the Nexus between Gross Domestic Savings and Economic Growth in Ethiopia: Evidence from Toda-Yamamoto Causality Approach. Int.J.Curr.Res.Aca.Rev. 6(9), 34-49.

doi: https://doi.org/10.20546/ijcrar.2018.609.005
Yamada, H. (1998). A Note on the causality between export and productivity: An Empirical reexamination. Economics Letters, 111-114.

Yinagre, D. (2016). Federal Democratic Republic of Ethiopia: Growth and Transformation Plan II (GTP II) (2015/16-2019/20) (Vol. 1). Addis Ababa: National Planning Commission.

Zapata, H. O., \& Rambaldi, A. N. (1997). Monte Carlo evidence on cointegration and causation. Oxford Bulletin of Economics and Statistics, 2, 285-295.

Zinyurugwi, T., \& Mapfumo, A. (2016). Investigating the relationship between domestic savings and economic growth in zimbabwe (1980-2015). AfroAsian Journal of Social Sciences, 7, 1-12. 